\title{
LIVING WITH AN ARCHAIC TREATY: SOlVING THE PROBleM OF THE WARSAW CONVENTION'S GOLD Clause
}

\author{
W K Hastings*
}

Article 22 of the Warsaw Convention for the Unification of Certain Rules Relating to International Carriage By Air limits carriers' liability by reference to the franc Poincaré or gold franc, a standard that no longer exists. Until the Montreal Protocols come into force or a revised and consolidated Convention is created, the author proposes a method that relies on cooperation between the executive and the courts to keep Article 22 alive and useful.

This is a short story about executive inertia and judicial timidity all over the world. What should a state do when a provision in a treaty to which it is bound becomes difficult to apply because that provision derives its meaning from a state of affairs that no longer exists? The answer need not be difficult, and in the case of the Warsaw Convention, the problem has been so thoroughly discussed that it is disconcerting to note that nothing has been done to resolve it for a decade. ${ }^{1}$ This article discusses how the United States, Australia, New Zealand and the United Kingdom have implemented, interpreted and applied

* Senior Lecturer in Law, Victoria University of Wellington.

1 Articles on the gold franc provision concerned mainly with the Article 22 cargo liability limitation include: Danziger, "Trans World Airlines, Inc $v$ Franklin Mint: The Judiciary's Problematic Role in Treaty Interpretation" (1985) 17 NYU J Int'l L and Pol 323; Note, "Franklin Mint Corporation v Trans World Airlines: Resolution of the Warsaw Convention Gold-Based Liability Limits Issue?" (1984) 18 Geo Wash J Int'1 L \& Econ 393; Note, Franklin Mint Corporation $v$ Trans World Airlines, Inc. (1983) 77 AJIL 320; Verville, "Warsaw Convention Federal Court Abrogates Article on Liability Limitation" (1982/83) 7 Suffolk Transnat'l L J 429; FitzGerald, "The Four Montreal Protocols to Amend the Warsaw Convention Regime Covering International Carriage by Air" (1976) 42 J Air L \& Com 273; Mankiewicz, "Modification de la 'Clause-Or' de la Convention de Varsovie de 1929 et des Protocoles d'Amendement, [1975] Ann. Francais de Droit International 788; Heller, "The Value of the Gold Franc - A Different Point of View" (1974) 6 J Mar L \& Com 73; Asser, "Golden Limitations of Liability in International Transport Conventions and the Currency Crisis" (1974) 5 J Mar L \& Com 645; Heller, "The Warsaw Convention and the 'Two-Tier' Gold Market" (1973) 7 J World Trade L 126; Lowenfeld and Mendelsohn, "The United States and the Warsaw Convention" (1967) 80 Harv L Rev 497. 
Article 22 of the Warsaw Convention for the Unification of Certain Rules Relating to International Carriage By $\mathrm{Air}^{2}$ in claims relating to lost or damaged cargo. ${ }^{3}$ This Article limits carriers' liability by reference to the franc Poincaré or gold franc, a standard that no longer exists. ${ }^{4}$ A method will then be proposed to keep Article 22 alive and useful until the Montreal Protocols come into force ${ }^{5}$ or a new Convention is ratified. Although this method relies on political will and better cooperation between the executive and the courts, that should not deter compliance with both the terms and the intention of the Convention.

\section{Article 22 of the Warsaw Convention}

The cargo liability limitation is found in Article 22(2)(a):

In the carriage of registered baggage and of cargo, the liability of the carrier is limited to a sum of two hundred and fifty francs per kilogramme...

The carrier's liability is not limited if the passenger or consignor has made a "special declaration of interest" at the time the package is handed over to the carrier; ${ }^{6}$ or if it is proved that the damage resulted from an act or omission of the carrier done with intent to cause damage or "recklessly and with knowledge that damage would probably result"; 7 or if cargo is loaded without an air waybill having been made out; ${ }^{8}$ or if the air waybill omits certain information. ${ }^{9}$ If there is no argument on the special declaration or the air waybill, or if liability has been admitted, then only the amount of damages remains to be assessed. "Two hundred and fifty francs per kilogramme" does not appear to be ambiguous ${ }^{10}$ until Article $22(5)$ is read:

2 Warsaw, 1929, 137 LNTS 11.

3 The Convention also limits carriers' liability in cases of personal injury and death, and lost or damaged baggage.

4 The Convention uses the term "franc". This is defined to a particular quantity and quality of gold, which is the same definition as that of the franc Poincaré.

5 The Warsaw Convention was amended by the Hague Protocol in 1955 (raising the limit for passenger deaths from 125,000 Poincaré francs to 250,000), the Guatemala City Protocol in 1971 (raising the limit for passenger deaths to 1,500,000 francs), and the Montreal Protocols in 1975 (inter alia, raising and converting the sums in which the limits are expressed into SDRs). The Montreal Protocols have not come into force.

6 Article 22(2)(a).

7 Article 25, which was added by the Hague Protocol in 1955.

8 Article 9.

9 Article 9.

10 There has been argument on what weight to use in the event the Article 22 limit applies. See Saba $v$ Air France 866 F Supp 588 (DDC, 1994)(as wilful misconduct was proved against Air France, the Article 22(2) 
The sums mentioned in francs in this Article shall be deemed to refer to a currency unit consisting of sixty-five and a half milligrammes of gold of millesimal fineness nine hundred. These sums may be converted into national currencies in round figures. Conversion of the sums into national currencies other than gold shall, in case of judicial proceedings, be made according to the gold value of such currencies at the date of judgment.

The expression "two hundred and fifty francs per kilogramme" in Article 22(2) is therefore not "francs" and indeed is not even a currency. It must be read as "two hundred and fifty currency units consisting of sixty-five and a half milligrammes of gold of millesimal fineness nine hundred". No such currency unit exists. If these currency units did exist, the last two sentences allow the conversion of these units into national currencies "according to the gold value of such [national] currencies". National currencies have not had a gold value since the 1970s. There are consequently two problems with a literal interpretation of Article 22(5): there is no such thing as a currency unit consisting of sixty-five and a half milligrammes of gold of millesimal fineness nine hundred; and there is no such thing as a national currency that has a gold value.

The intentions of the drafters of Article 22(5) are well documented. Domestic French francs, the value of which was determined by French law, were explicitly rejected as the Article 22 standard because, in the words of the much-quoted M Pittard, ${ }^{11}$ the Swiss representative at the 1929 conference from which the Convention emerged:

Naturally, one can say "French franc" but the French franc, it's your national law which determines it, and one need have only a modification of the national law to overturn the essence of this provision. We must base ourselves on an international value, and we have taken the dollar. Let one take the gold French franc, it's all the same to me, but let's take a gold value.

In rejecting a domestic currency as the way to express the Article's limitation on carrier liability, the drafters pursued two objectives: a uniform internationally referenced limit that would be both independent of domestic law and capable of application in any domestic legal system; and a limit that would have a value that is constantly and consistently related to the value of the cargo and baggage subject to claims, thus remaining neutral for both

interpretation issue became moot) and Norwood v American Airlines 16 Avi Cas (CCH) 17,218 (DC Sup Ct Small Clms 1977)(the weight of the damaged cargo is the proper weight to use).

11 Minutes of the Second International Conference on Private Aeronautical Law, Warsaw, October 4-12, 1929, 89-90, quoted in Danziger, above n 1, in Trans World Airlines v Franklin Mint 466 US 273 (1983) by Stevens J, dissenting, at 266-7, and in SS Pharmaceutical Co $v$ Qantas Airways Ltd [1989] 1 Lloyd's Rep 319 at 323 (NSW SC), appeal dismissed at [1991] 1 Lloyd's Rep 288 (Kirby P dissenting). 
carriers and consignors. ${ }^{12}$ The challenge is to achieve these objectives using the words of the Convention that have ceased to have their original meaning.

The expression "the gold value of such [national] currencies" was meant to achieve uniformity and predictability as an expression of value. This could be achieved if in fact the expression was reversed to read "the current [national] value of gold." The immediately preceding sentence refers to the conversion of sixty-five and a half milligrammes of gold of millesimal fineness nine hundred into a national currency, so to read the last sentence in this way does no great damage to the drafters' intention, and in fact, probably better achieves it. If this was the intention of the drafters, it does not really matter that there is no currency unit consisting of sixty-five and a half milligrammes of gold of millesimal fineness nine hundred because the drafters intended that such a currency unit be the value of that amount and quality of gold. The conversion provision likewise was intended to operate on the assumption that that amount and quality of gold had a value that could be expressed in a national currency. While it is true that gold had no value other than an "official" value when the Convention was drafted, it is the fact that gold was chosen to achieve the objectives of international uniformity and predictability of value that matters, not that any given currency had a gold value. The point of paragraph 5 was that gold had an internationally-referenced value. It still does as a commodity. The limit referred to in Article 22(2)(b) could be calculated as 250 times the value in domestic currency of sixty-five and a half milligrammes of gold of millesimal fineness nine hundred per kilogram of damaged cargo.

The Convention also anticipated that the value of this amount and quality of gold could fluctuate. It required states to convert this sum into national currencies, in the case of judicial proceedings, "at the date of judgment." There would be no need to specify a date unless the value of gold expressed in a national currency could fluctuate. Not only does this sentence somewhat diminish an argument that market price of gold cannot be used because the drafters could not have anticipated fluctuations (although the degree of fluctuation in the 1970s and 1980s certainly could not have been anticipated), it also requires courts to know the value of gold at the date of judgment. Courts could rely on the submissions of counsel or take judicial notice of such value in relatively stable times. Other methods may be necessary in less stable times. But the Convention is clear and mandatory. It is the value of gold at the date of judgment that must be used to determine the damages awarded when the Article 22(2) limit applies.

The Montreal Protocols of 1975 amended the limitation on liability for damage to cargo to 17 SDRs per kilogram. The SDR was to be calculated in accordance with the method of

12 Rogers CJ Comm D, SS Pharmaceutical Co v Qantas Airways Ltd [1989] 1 Lloyd's Rep 319 at 328 (NSW SC); Trans World Airlines $v$ Franklin Mint 466 US 243, 255. 
valuation applied by the IMF. ${ }^{13}$ The Montreal Protocols also allowed states which were not members of the IMF and whose law did not permit the application of SDRs as a method of calculating damages, to use the old "sixty-five and a half milligrammes of gold of millesimal fineness nine hundred" standard. It was called a "monetary unit" instead of a "franc". The last two sentences of the old Article 22(5) were tidied up to read:

These sums may be converted into the national currency concerned in round figures. The conversion of these sums into national currency shall be made according to the law of the State concerned.

This wording removes the awkwardness of the phrase "gold value of such currencies" and achieves the intent of the drafters in 1929, which was that the value in national currency of sixty-five and a half milligrammes of gold of millesimal fineness nine hundred would be used to award damages up to the limit of 250 of these units/francs per kilogram.

Both the SDR and non-SDR regimes proposed in the Montreal Protocols went some way to modernise the archaic gold provisions of Article 22. The use of SDRs achieved the objective of an internationally-recognised standard removed from direct national influence, and the objective of a relatively stable and modern method of calculation. The reworking of Article 22(5) for countries which chose not to use SDRs, while continuing to be tied to the value of gold, explicitly stated that the value of the stated amount and quality of gold was to be converted into national currencies. Although this was stated to be "according to the law of the State concerned", thus raising a forum-shopping spectre, by removing the word "franc", substituting the word "monetary unit", and requiring sums of gold to be converted into national currencies, the drafters appeared to emphasise the market value of gold. While less satisfactory than the SDR provisions because of gold's less stable value, the reworked Article 22(5) at least removed confusion caused by the use of the word "franc" and created the potential for more realistic damage awards under Article 22(2).

The quid pro quo for substituting SDRs for all other states parties to the Warsaw Convention was however the removal of the Article 25 exception to the Article 22 personal injury liability limitation. ${ }^{14}$ The United States Senate also expressed difficulty with a mandatory surcharge on all tickets to finance a Supplemental Compensation Plan proposed by the United States as a condition for ratification of the Montreal Protocols, and was

13 Article 22(4). The SDR, or Special Drawing Right, is the unit of account of the International Monetary Fund (IMF). Its value is determined daily on the basis of a basket of five currencies: the American dollar; the deutsche mark; the French franc; the Japanese yen; and the pound sterling.

14 Article 25 remained in place for cargo claims. 
concerned about the effect of the nearly absolute liability limitation on safety standards. ${ }^{15}$ The inability of the United States Senate to pay this price for modernising and raising the liability limitation ceiling resulted in the Montreal Protocols not achieving the necessary thirty ratifications required to enter into force. ${ }^{16}$ This has resulted however in perpetuating the very regime the objectors abhor. ${ }^{17}$ It has also resulted in continuing problems of interpretation and application of Article 22(5), made seemingly more futile because of the ridiculously low awards that often result from these tortuous interpretations by courts and executives all over the world.

\section{State Practice}

The difficulty in interpreting and applying Article 22(5) has resulted in inconsistent practice, both within and among states. The international standardisation the Convention sought to achieve has been subverted, and enormous forum shopping opportunities created. Although Article 22 appears largely aimed at courts, the executive branch in many countries has assisted in creating this lack of uniformity, both by not ratifying the Montreal Protocols and by not acting creatively to keep Article 22 alive in new economic circumstances.

\section{The Executive}

In New Zealand, the Convention as amended by the Hague Protocol is scheduled to the Carriage by Air Act 1967, and is given force of law by s. 7 of that Act. In anticipation of the entry into force of the Montreal Protocols, the Convention as amended by the Hague and Montreal Protocols is scheduled to the Carriage by Air Amendment Act 1990. This Act received royal assent on 8 August 1990 and was stated by s. 1(2) to enter into force on 1 September 1990. On 31 August, the day before the Montreal Protocols were to become New Zealand law, the Carriage by Air Amendment Act (No. 2) 1990 received royal assent. This second amendment statute repealed s. 1(2) of the first amendment statute, and provided that the first amendment statute would come into force on a date to be appointed by the Governor-General by Order-in-Council. No such Order-in-Council has been promulgated which means the Montreal Protocols form no part of New Zealand law, although for a

15 Senate Committee on Foreign Relations, Montreal Aviation Protocols 3 and 4: Report Together with Minority Views, Senate Executive Report No. 21., 101st Congress, 2d Session, 1990; Matte, "The Warsaw System and the Hesitations of the US Senate" (1983) 8 Annals of Air \& Space L 151.

16 Article VIII(1) of the third Protocol and Article XVIII(1) of the fourth Protocol. This of course raises the question of why so many ratifications are required before these Protocols enter into force. The effect of their entry into force is to create a new treaty called the "Warsaw Convention as amended at The Hague, 1955, at Guatemala City, 1971, and by the Additional Protocols No. 3 and 4 of Montreal, 1975." See Article IX(2) of the third Protocol and Article XIX(2) of the fourth.

17 This point is also made by Cotugno, "No Rescue in Sight for Warsaw Plaintiffs from Either Courts or Legislature - Montreal Protocol 3 Drowns in Committee" (1993) 58 J Air L \& Com 745, 792. 
hectic three weeks in August 1990 it looked as though they might. It is the Convention as amended by the Hague Protocol that continues to have force in New Zealand.

The Article 22 liability limitations are given force of law by s. 10 of the Carriage by Air Act 1967. Section 10(4) states that

The Minister of Finance may from time to time, by notice in the Gazette, specify the respective amounts which for the purposes of the said Article 22, and in particular of paragraph (5) of that Article, are to be taken as equivalent as the sums expressed in francs which are mentioned in that Article.

The amounts are specified in the Carriage by Air (New Zealand Currency Equivalents) Notice $1984 .^{18}$ With respect to the cargo liability limitation in Article 22(2), the Minister fixed the value of 250 francs at NZ\$33.75. There is no indication of the method used by the Minister to calculate this conversion. This is still the amount 12 years later.

In the United Kingdom, the Carriage by Air and Road Act 1979 amended the Carriage by Air Act 1961 to incorporate the Montreal Protocols. Section 4(1) of the 1979 amended Article 22 of the Convention (which forms part of the Carriage by Air Act 1961 as Schedule 1 of that Act) to, among other things, substitute the words "17 special drawing rights" for the words "two hundred and fifty francs". To convert SDRs into sterling, s 5 provided that:

the value on a particular day of one special drawing right shall be treated as equal to such a sum in sterling as the International Monetary Fund have fixed as being the equivalent of one special drawing right ... for that day ...

Subsection (2) went on to provide that a Treasury certificate "shall be conclusive evidence of those matters for the purposes of the preceding subsection ..." With respect to judicial or arbitral proceedings, the words "a particular day" and "for that day" must refer to the "date of the judgment" specified in Article 22(5) as no other day is relevant in the context of such proceedings in the Convention. No Order in Council bringing these provisions into force with respect to carriage by air has been made. The United Kingdom, like New Zealand, has legislation implementing the Montreal Protocols on the statute books, but not in force. The Convention limitations in the United Kingdom remain based on gold francs. The Carriage by Air (Sterling Equivalents) Order 1986, ${ }^{19}$ like the $1984 \mathrm{New}$ Zealand Notice, translates gold francs into sterling. The Article 22(2) 250 franc limit has been converted to $£ 13.63$. Unlike the New Zealand Notice however, an explanatory note which does not form part of the Order states that "[t]he sterling equivalents have been calculated by reference to the Special Drawing Right (SDR) value of a gold franc converted

$181984 / 326$.

19 SI 1986 No 1778. 
into sterling at current market rates." The method of calculation appears to be the market value of that quantity and quality of gold expressed in SDRs, a figure which is then converted into sterling. The use of SDRs as a conduit of calculation, instead of taking the daily sterling price of gold, appears intended to moderate fluctuations in the market value of gold caused by the daily management of any one country's (or person's) monetary policies.

The relevant Australian statute is the Civil Aviation (Carriers' Liability) Act 1959. This implements the Warsaw Convention as amended by the Hague Protocol and consequently suffers, like New Zealand and the United Kingdom, from the same references to gold. An attempt was made in 1982 to raise the limits on liability for personal injury and baggage damage by enacting the Civil Aviation (Carriers' Liability) Amendment Act 1982 which received royal assent on 6 September 1982, but the provisions actually raising the limits were to come into force on a date to be fixed by a proclamation that has never been made. The next attempt was the Civil Aviation (Carriers' Liability) Amendment Act 1991. Section 4 of the 1991 Act came into force on 11 December 1991. Section 4 purports to amend s. 8 of the principal 1959 Act by referring to the Montreal Protocols which are scheduled to the 1991 Act, and substitutes the following provision for s. 9 of the 1959 Act:

In assessing under this Act the damages recoverable in an action against a carrier, a court must convert all relevant SDR amounts into Australian dollars, using the exchange rate published by the Reserve Bank of Australia, being the rate that applies as at the day on which the court's judgment is given.

This provision does not give the Montreal Protocols the force of law in Australia. That is done by s. 9 of the 1991 Act, which, as one might have guessed, is to come into force on a date to be fixed by a proclamation that has not yet been made. There are consequently no "relevant SDR amounts" to which the above provision might apply.

While this is yet another example of ineffective statutes sitting in the statute books waiting for executive ratification of the Montreal Protocols and their proclamation into domestic law, the situation in Australia differs from that in the United Kingdom and New Zealand in that there is no subsidiary legislation or statutory instrument converting the Convention gold franc amounts into Australian currency. In all three countries, legislative intent that the Montreal Protocols become law has been demonstrated by the passage through Parliament of implementing legislation. This intent has been obstructed in all three countries at an international level by the inability of the Protocols to attract the required number of ratifications to bring them into force, and domestically by the executive not ratifying the Protocols. Implementing legislation cannot come into effect because of executive blockage at the domestic and international levels. In New Zealand and the United Kingdom, the executive has further impeded the legislature's intent with subordinate legislation freezing a conversion rate that is over a decade old. Although the United Kingdom has been up front about using SDRs in its method of calculating conversion, the main advantage of 
SDRs, which is their ability to reflect current values independent of any particular country's monetary policies, is lost by the unchanging nature of a fixed amount stated in a statutory instrument. It is difficult to say, from a court's point of view, which is preferable: the existence of a statutory instrument that freezes the court's ability to make a realistic award; or the absence of such a statutory instrument that forces the court to step into the breach by choosing one of any number of conversion methods, all of which have judicial support somewhere, but none of which has the seal of current executive approval.

\section{The Judiciary}

This difficulty is reflected in the array of decisions by domestic courts. In the absence of executive guidance, courts have converted the sum of "two hundred and fifty francs per kilogramme" in Article 22(2) using four methods, each of which produces very different amounts in local currency. These methods have been thoroughly discussed elsewhere, ${ }^{20}$ but for convenience are summarised here:

(a) The market price of gold interpretation. The argument in favour is that the framers of the Convention had in mind the value of a certain weight of gold so that awards of damages could remain current. The argument against is that to apply a market rate would not be in the interests of predictability and stability of what was meant to be a predictable and stable international limit. ${ }^{21}$

(b) The last official value of gold interpretation. The argument in favour is stability and constitutional deference by the courts to an executive or legislative determination. The argument against is that the last official value of gold is completely out of touch with economic reality and defeats the ability of the Convention to offer a liability limit based on current values. ${ }^{22}$

(c) The SDR interpretation. The argument in favour is that it maintains the ability of the Convention to fix liability limits by reference to a stable currency, and that it is up

20 By judges in SS Pharmaceutical Co Ltd $v$ Qantas Airways Ltd [1989] 1 Lloyd's Rep 319 (NSW SC) and Trans World Airlines Inc v Franklin Mint Corp 104 SC 1776 (1984); and by academics in the references cited in footnote 1.

21 SS Pharmaceutical Co Ltd $v$ Qantas Airways Ltd [1989] 1 Lloyd's Rep 319 (NSW SC), appeal dismissed by NSW CA at [1991] 1 Lloyd's Rep 288. See also the list of cases cited by Rogers CJ Comm D in SS Pharmaceuticals [1989] 1 Lloyd's Rep 319, which is identical to the list of cases cited by Franklin Mint in the US Supreme Court case, a list which is cited by Danziger, above note 1, 348: Cosida SpA $v$ BEA, Milan Ct of App No 2796/77, 9 June 1981; Kuwait Airways Corporation v Sanghi, Court of the Principal Civil Judge, Bangalore, India, 11 August 1978; Balkan Bulgarian Airlines $v$ Tanmaro, Court of Milan, Italy, [1982] 17 Eur Tr L 330; Florencia, Cia Argentina de Seguros, SA v Varig, SA , Fed CA Buenos Aires, Argentina, 27 August 1976 [1977] Uniform L Rev 198; Zakoupolos v Olympic Airways Corp, No 256/74, Ct of App, 3d Dep't, Athens, Greece, 15 February 1974.

22 Trans World Airlines Inc v Franklin Mint Corp 104 SC 1776 (1984). 
date. This is the interpretation provided by the First Additional Montreal Protocol of 1975, which is not in force, and the interpretation used in the UK Carriage by Air (Sterling Equivalents) Order 1986 and by courts in Italy, Austria and The Netherlands. The argument against is that it has nothing to do with the words of Article 22(5) and would amount, in effect, to a rewriting of the paragraph. ${ }^{23}$

(d) The current value of the franc interpretation. The argument in favour is that the franc is referred to in Article 22(5), and since it no longer has a gold value, the current, easily ascertainable, market value of the franc itself must be used. The argument against is that it was the intention of the framers of the Convention to put the liability limit beyond the control of any one country, in other words, to "internationalise" it. Continued reference to the franc would defeat this purpose. This has been recognised in France itself. ${ }^{24}$

Each of these interpretations are supported by courts which of course operate in the context of their own domestic statutes, subordinate legislation and constitutional customs concerning treaty implementation and interpretation. These variants play no insignificant role in the overall appearance of disarray in the interpretation and application of the Warsaw Convention even though this is exactly what the Convention was designed to overcome. For example, in the United States, the Convention is self-executing. In the absence of any executive or legislative indication of denunciation as required by Article 39, the Supreme Court in Franklin Mint held that the doctrine of changed circumstances could not be successfully argued by a private party. ${ }^{25}$ The Civil Aeronautics Board (CAB) was delegated power to make the conversion required by Article 22 which it last did in $1974 .{ }^{26}$ This determination had not changed since gold was demonetised, but since the conversion represented the executive's determination, the Court was bound to uphold it unless it was contrary to the Convention itself. As the gold clause has no current meaning, this at first

23 State of The Netherlands $v$ Giants Shipping Corp, Judgment of 30 May 1981, Hoge Raad der Nederlander, Neth. Rechtspraak van de Week 321, cited in Danziger, above n 1, 362, and by Rogers CJ Comm D in SS Pharmaceuticals, above $\mathrm{n}$ 21. See also Linee Aerea Italiane $v$ Ricciole, Civil Court of Rome, 14 November 1978; Kislinger $v$ Austrian Airtransport, No 1 R 145/83, Commercial Court of Appeals of Vienna, Austria, 21 June 1983; Rendezvous-Boutique-Parfumerie Friedrich und Aolbine Breittinger GmbH v Austrian Airlines, No $14 \mathrm{R}$ 11/83, Court of Appeals of Linz, Austria, 17 June 1983; Kim v Korean Air Co Ltd , Seoul Court of Appeal, 30 November 1987, also cited by Rogers CJ Comm D. SDRs are now the basis upon which Article 22 calculations are made in France: Chassagnac v Air France, Cour d'Appel de Paris (1er Ch), 22 September 1989, (1989) 43 RFDA 550.

Only two cases are ever cited in support of this interpretation: Kinney Shoe Corp v Alitalia Airlines 15 Avi Cas 18,509 (SDNY, 1980) which has been superseded by Franklin Mint; and Chamie $v$ Egyptair, Cour d'Appel de Paris, (1981) 35 RFDA 148, which was reversed by the Cour de Cassation (1983) 37 RFDA 223 and which has been superseded by Chassagnac, (1989) 43 RFDA 550. 
glance seemed an impossible task, but the court decided that continued use of the last official price of gold was "reasonably stable" and "predictable", thus meeting several of the purposes of the Convention. ${ }^{27}$ This is less an argument based on any inherent value of old gold, and more an argument that it remains the province of the executive to implement Article 22, and until the executive indicates that it has modernised its interpretation of Article 22, the last executive interpretation is the only one the courts can look to. Indeed, this point is driven home by the dissenting Justice in Franklin Mint, Justice Stevens, who said, "The task of revising an international treaty is not one that this Court has any authority to perform." 28

Franklin Mint's deference to executive implementation of Article 22 is also the approach likely to be taken by Commonwealth courts where the executive has made its view known, as it has in the United Kingdom and New Zealand. The existence of a statutory instrument in each of these countries appears to have either encouraged settlements or encouraged litigants to litigate elsewhere. In Australia however, the executive has not interpreted Article 22, with the result that the New South Wales Supreme Court in SS Pharmaceutical v Qantas Airways ${ }^{29}$ was left to give meaning to an archaic clause in a treaty in the absence of executive direction. That case involved damage to pallets of pharmaceutical items left out in the rain at Sydney airport. Rogers CJ Comm D held that Article 25 applied and that consequently the defendants were not entitled to limit their liability under Article 22. Nevertheless, Rogers CJ Comm D gave an extensive interpretation of the Article 22 gold clause. After a process of eliminating SDRs because the government indicated that it was exploring other avenues in light of the failure of the Montreal Protocols, ${ }^{30}$ eliminating the last official price of gold because it "would have as much relevance to proper levels of compensation to fix a Roman coin as the appropriate standard" 31 , and eliminating the current French franc because it "flies flatly in the face of what was decided at the Warsaw Convention"32, Rogers CJ Comm D applied the current market price of gold interpretation. Although deciding it was "destructive of stability" ${ }^{33}$ His Honour stated that the "only gold

27 Above n 25, 256.

28 Above $n$ 25, 283. Justice Stevens of course disagreed with the majority's view that the court was deferring to the executive branch's interpretation of the gold clause. He argued that the majority would not have been so deferential if the CAB had used a method other than the last official value of gold, and that by choosing this outdated method, the majority was effectively, and unconstitutionally, rewriting the treaty. SS Pharmaceutical Co Ltd $v$ Qantas Airways Ltd [1989] 1 Lloyd's Rep 319 (NSW SC), appeal dismissed by NSW CA at [1991] 1 Lloyd's Rep 288. 
price that can be used is the only price currently in existence, the free market price." ${ }^{34}$ An appeal to the New South Wales Court of Appeal on Rogers CJ Comm D's finding that the case was within Article 25 was dismissed. ${ }^{35}$ In his dissenting judgment however, Kirby $P$ as he then was thought that if the appeal had been upheld on the Article 25 point, then further argument was necessary on the Article 22 point. ${ }^{36}$ His Honour did however associate himself with Rogers CJ Comm D's request "that the Australian Government should give urgent attention to the defects in the law called to light by this case." 37

\section{Interpreting New Zealand Implementing Legislation}

Taken together, the two main precedents to which a New Zealand court may look for guidance in an Article 22 case present an unsatisfactory situation. One relies on the last executive interpretation of the gold clause, which is the last official price of gold. The other calls this interpretation inappropriate, and uses, by a process of elimination, the current market value of gold, an interpretation called into question, but not decided, on appeal. Unless the Carriage By Air (New Zealand Currency Equivalents) Notice 1984 can be challenged, it will be the 12 year-old values set out in that Notice that a New Zealand court will apply.

The self-executing nature of the Convention in the United States makes the Convention effective as part of American domestic law. It is domestic legislation that gives the Convention effect in New Zealand. Section 7 of the Carriage by Air Act 1967 gives the Convention as amended by the Hague Protocol the force of law in New Zealand. Section 10(4) states that the Minister of Finance "may ... specify the respective amounts which for the purposes of the said Article 22, and in particular of paragraph (5) of that Article, are to be taken as equivalent to the sums expressed in francs . . " ${ }^{38}$. Section 10(4) could be read as allowing the Minister to specify an amount in Article 22(5), but as there is no amount in Article 22(5), the reference to Article 22(5) in section 10(4) relates to "purpose" rather than "amount". The Act does not impose any duty on the Minister to specify amounts. Parliament has delegated authority to the Minister to specify amounts at her or his discretion. This is often done with respect to implementing specific or changeable details of ratified treaties. It is an authority which the Minister, in his discretion, exercised with respect to paragraphs (1), (2)(a) and (3) of Article 22, for the purpose set out in Article 22(5). The purpose set out in Article 22(5) is the purpose of conversion of gold franc amounts into domestic currency

\footnotetext{
34 Above $n$ 29, 328. My emphasis.
} 
which, in the case of judicial proceedings, is to be made at the date of judgment. The Minister did this in the 1984 Notice. So did the CAB did in its 1974 Order and the United Kingdom in its 1986 Order. The only difference is that the CAB based its conversion on the last official price of gold and the United Kingdom based its conversion on the value of gold expressed in SDRs translated into sterling at the date of the drafting of the Order. There is no indication in the New Zealand Notice as to the method used. This situation creates the potential for a New Zealand precedent similar to the criticised Franklin Mint judgment.

It is possible to argue that the Minister did not take into account the clear words of the Convention in gazetting the 1984 Notice. This argument can also be made with respect to the United Kingdom Order and could have been made with respect to the CAB Order, but appears not to have been. The 1984 Notice refers to the "sums mentioned in francs" in Article 22, and thus appears to be what Article 22(5), at first glance, requires. Nevertheless, Article 22(5) states a mandatory temporal condition in the case of judicial proceedings. It requires conversion of the sums stated in francs to be "at the date of the judgment". While the 1984 Notice will obviously be alive at the date of any subsequent judgment, the Convention requires conversion to take place at the date of judgment, not the application of an amount that has already been converted before the judgment, which is what the 1984 Notice does. As s. 7 gives the entire Convention force of law, and as s. 10(4) makes explicit reference to Article 22(5), it is possible to argue that the 1984 Notice is not a Notice which meets the requirements of Article 22(5). In other words, the 1984 Notice has nothing to do with Article 22(5), an Article having force of law in New Zealand, because the Notice can never be a "conversion ... according to the gold value of such currencies at the date of judgment." If this is the case, a New Zealand court will be in the same position as the New South Wales Supreme Court, and will have to look to state practice and the intention of the framers to interpret an Article without modern meaning. Either way, the situation is unsatisfactory.

\section{IATA Practice}

At its 51st annual general meeting in Kuala Lumpur on 31 October 1995, IATA adopted the Intercarrier Agreement on Passenger Liability. ${ }^{39}$ Although mainly concerned with liability for personal injury and death, the carriers opted to waive the Warsaw limits subject to two conditions: the full recoverable compensatory damages will be determined according to the law of the domicile of the passenger; and that the Warsaw defences remain available to the carrier. This is an agreement amongst private parties. It cannot amend the Warsaw Convention. Indeed, Article 32 expressly addresses such agreements and declares them void except for arbitration agreements relating to cargo claims. On the other hand, the

39 I am indebted to Professor Michael Milde of McGill University for allowing me to read his as yet unpublished paper entitled "Warsaw Requiem or Unfinished Symphony" which discusses how the airlines have coped with the inability of states to update the Warsaw regime. 
limitation of liability provisions of Article 22 exist for the benefit of the carriers. If the carriers choose to waive them, only insurers could complain, and they were consulted by the carriers before the Kuala Lumpur meeting. ${ }^{40} \mathrm{~A}$ great many states and national carriers have voluntarily increased their liability, and have expressed their liability in SDRs. ${ }^{41}$

The continued existence of the gold clause alone is making the Warsaw Convention almost daily increasingly archaic, and forcing states and carriers into implementing what they genuinely perceive to be realistic remedial measures. The consequence is that such unilateral activity rebounds on the Warsaw regime, outdating it even more rapidly. Executive attention needs to be turned away from unilateral bandaging and towards a solution that preserves the universality of the Convention regime.

\section{A solution}

Courts can hardly be blamed for the confusion resulting from reluctant judicial intervention in an area that ought to be the preserve of the executive. Only the executive can enter into treaties; only the executive can amend them when they cease to be of use, or in the case of the Warsaw Convention, when they become a hindrance to achieving legal uniformity amongst states and justice amongst individual claimants. To devote executive energies to unilateral solutions is to divert executive energies from an international solution, and to make it more difficult to achieve an international solution when the opportunity finally arises. What needs to be done?

Domestically, there should be no statutory instrument fixing the value of the "franc" in Article 22. A figure 12 years out of date is worse than no figure at all. Instead, the words of Article 22(5) should be adhered to. They require conversion of the sums mentioned in Article 22 to occur at the date of judgment. The most the executive should do is indicate to the courts the method of conversion to be used. Either the market value of sixty-five and a half milligrammes of gold of millesimal fineness nine hundred expressed in domestic currency should be used, or the market value of sixty-five and a half milligrammes of gold of millesimal fineness nine hundred expressed in SDRs which is then converted into domestic currency should be used. The latter method is probably better because the use of SDRs will tend to moderate market fluctuations in the value of gold. Courts could then request either the Reserve Bank or the Minister of Finance or Foreign Affairs to provide the amount in domestic currency using the above method on the day of judgment. Indeed, this is the practice in France. ${ }^{42}$ This will involve some co-ordination between the courts and the executive, but

40 Above $n$ 39, 8.

41 Gazzetta Ufficiale della Republica Italiana, Roma, No. 168, 19 July 1988 applying to Alitalia everywhere, and to foreign carriers within Italy. 
nothing that could not be easily achieved in the electronic era. It also satisfies the wording of the Convention as it stands.

Internationally, if the Montreal Protocols are not to be ratified - they are, after all, 21 years old now and themselves increasingly out of date - something has to be done to stop the break-up of the Warsaw system. The main virtue of the Montreal Protocols was the use of SDRs instead of gold francs as a unit of account. This should be retained. Current disadvantages of the Montreal Protocols are that the liability limits are out of date, and perhaps even unnecessary in light of current IATA thinking; and that the new instrument to be created on their entry into force was to be an unwieldy amalgamation of years of amendments to the Warsaw Convention. What is needed is a consolidation of international carrier liability provisions into one coherent instrument that uses SDRs as an international unit of account. A new international conference needs to be convened for such a purpose. Article $\mathbf{4 1}$ provides that any party may "call for the assembling of a new international Conference in order to consider any improvements which may be made in this Convention." Participation of the carriers is essential. What better country to call for such a conference than the home of one of the world's leading international carriers - New Zealand.

\section{Les difficultés d'application de l'article 22 de la convention de Varsovie}

L'article 22 de la Convention de Varsovie pour l'unification de certaines règles relatives au transport international aérien, fixe un plafond de la responsabilité des transporteur aérien par référence au Franc Poincaré ou encore au Franc or, référence qui à ce jour n'existe plus. La difficulté de l'interprétation et de l'application de cet article sont à l'origine de pratiques variées et souvent contradictoires tant à l'intérieur d'un pays donné ou encore dans les relations entre pays entre eux.

Bien que les dispositions de l'article 22 soient prévues pour etre utilisée par les tribunaux, les pouvoirs exécutifs de chaque pays se sont ingéniés à créer les difficultés que l'on rencontre aujourd'hui, soit en ne ratifiant pas purement et simplement la Convention de Varsovie, soit lorsque la ratification avait eue lieu, en ne prenant pas les décisions nécessaires pour maintenir une application des termes de l'article 22 mieux adaptée aux nouvelles circonstances économiques.

En Angleterre, Australie et Nouvelle Zélande, la volonté d'intégrer les termes de la Convention dans le droit positif ne fait aucun doute. Reste que dans ces trois pays, les bonnes intentions n'ont pas été suivies d'effets soit parce que la ratification n'a pas eu lieu, soit parce que le nombre des pays qui l'avaient ratifiés était si peu important qu'en pratique son exécution devenait sans objet. En Nouvelle Zélande et en Angleterre par exemple, le pouvoir exécutif a mis un frein à la volonté du législateur en subordonnant son applicabilité à l'utilisation d'un taux de change qui datait depuis plus de 10 ans. 
Pour les tribunaux, il devient alors difficile de savoir, ce qui est préférable: l'existence d'une disposition qui dans la pratique empêche d'allouer une indemnisation adéquate, ou l'absence d'une telle disposition qui force les juridictions à avoir recours à des méthodes de substitution qui si elles reposent sur des dispositions légales qui existent par ailleurs dans d'autres domaines du droit, n'en iront pas moins à l'encontre des désirs du corps législatif qui souhaiterait voir appliquer les termes de la Convention de Varsovie.

Dans l'attente de la promulgation des dispositions du Protocole de Montréal ou d'une nouvelle version de la Convention de Varsovie, l'auteur suggère d'avoir à une méthode qui reposerait sur une étroite collaboration entre les tribunaux et l'exécutif, permettant ainsi aux dispositions de l'article 22 de continuer à prospérer. Les termes employés par ce article doivent etre respectés. Ils imposent la conversions des sommes allouées au jour de la décision. Le moins que l'exécutif puisse faire est d'indiquer clairement quelle méthode de taux de change il convient de retenir. Soit la valeur marchande de 65, 5 milligramme d'or pur à $99 \%$ exprimée dans la monnaie du pays où le jugement sera rendu, soit la valeur marchande de cette même quantité d'or exprimée en SDR, qui sera par la suite traduite en valeur de la monnaie du pays où la decision sera rendue. Cette derniere approche apparaît la mieux adaptée en l'espèce, car elle tend à réduire les risques de fluctuations des cours de l'or. Les tribunaux pourraient alors demander soit à leur banque central ou encore à leur Ministre des Finances ou des Affaires Étrangères de leur indiquer le montant correspondant en utilisant les méthodes ci-dessus décrites. C'est en fait la pratique aujourd'hui suivie en France. 